\title{
Correction of energometabolic disorders atsignificant iodine deficiency in calves
}

\author{
Alexei Evglevskiy ${ }^{1}$, Olga Shvets $^{2}$, Tatyana Mikhaleva ${ }^{2}$ \\ ${ }^{1}$ Kursk Federal Agrarian Scientific Center, d. 70 b, st. Karl Marx , 305021 Russian Federation \\ ${ }^{2}$ Kursk State Agricultural Academy named after I.I. Ivanov, d. 70, st. Karl Marx , 305021 Russian Federation
}

\begin{abstract}
The paper is devoted to the development and use of theiodomethaboliccomplex based on iodine-iodide with polyvinyl alcohol (iodinol) and succinic acid.It was found that the inclusion of succinic acid or sodium succinate in a similar concentration in the composition of iodinol allowed not only qualitatively improving the pharmacological properties of iodinol, but also obtaining an energometabolic composition suitable for parenteral administration. The results of using the iodomethabolic compositionrevealed that with the parenteral administration to calves with clinically pronounced iodine deficiency, it provides effective normalization of pathological biochemical processes in the body of calves (metabolic effect) and pronounced activation of energy metabolism (energy effect), and in general, an energometabolic effect that ensures clinical recovery of animals from iodine deficiency.
\end{abstract}

\section{Introduction}

One of the global and vital problems of humanity is iodine deficiency. Andthis isnotfortuitous. Iodine deficiency disorders are the most common noncontagious pathology in the world.

More than $50 \%$ of constituent entities of the Russian Federation are iodine-deficient, more than $60 \%$ of the population lives in regions with a naturally-related deficiency of this microelement [1-3].

Environmental monitoring of iodine in the arable layer of soils of the districts of Kursk Region indicates a low level of security and boundary situation of the biogeochemical danger of the endemic goitre[4 ].

Iodine performs the same functions in mammals as in the human body. Dairy cattle that do not receive additional iodine may not receive a necessary minimum of iodine, even in areas that are not included in the goitrebelt. Highly productive cows receiving large amounts of concentrates containing soy meal or other iodine binding agents may need additional iodine [5].

Animals, especially agricultural animals, are as sensitive to iodine deficiency as humans.

Hemken R.W. [6] studied the role of iodine deficiency in the development of perinatal weak calf syndrome. Five cows were given an iodine deficient diet (average iodine concentration - $0.06 \mathrm{mg} / \mathrm{kg}$ of dry matter) and six were given a diet sufficient in iodine content (average iodine concentration $-1.45 \mathrm{mg} / \mathrm{kg}$ of dry matter). The diet consisted of wheat and soybean flour with the addition of minerals and vitamins (with or without iodine) and was given to cows during the last four to five months of pregnancy.
Iodine deficient diet caused clinical-pathological changes and abnormal changes in the thyroid gland of both cows and their offsprings [6].

Until recently, the possibility of using iodine preparations to correct pathobiochemical processes in industrial animal husbandry was almost neglected [1]. This is largely caused by the lack of understanding of the role of iodine in the health of productive animals.

Of all active microelements, iodine is the only anion, which largely determines its importance in exchange processes. Iodine introduced into the body is almost all concentrated in the thyroid gland and is used to form its hormone - thyroxin. Sufficient supply of iodineaccelerates the assimilatory phase of the exchange, which leads to an increase in the absorption of nitrogen, calcium, phosphorus, iron, cobalt by the body tissues.

Hormonal iodine is necessary as a catalyst in the methylation process, as a result of which enzymes are formed from pro-enzymes, as well as for the synthesis of protein compounds of iron, zinc, copper, cobalt (hemoglobin, hemocyanin, cobalamin, etc.). Hormonal iodine stimulates and sensitizes the sympathetic nervous system and thereby indirectly increases the adaptive and protective immunobiological actions of the body.

With long-term insufficient admission of iodine to the body, iodine metabolism is disrupted thus developing the lack of thyroid hormone.

Proliferative processes are developing in the thyroid gland leading to its hyperplasia, which to a certain extent restores the metabolic disorder caused by iodine deficiency. But if iodine deficiency is aggravated by a number of factors that weaken the adaptive capabilities of an organism, then a specific goiter hyperplasia of the thyroid gland develops, which increasesthe metabolic processes in the body.

\footnotetext{
* Corresponding author: oshvec@yandex.ru
} 
Randhawa C.S. et al. [5] determined the prevalence of iodine deficiency in mongrel cows and concluded that the average prevalence of iodine deficiency was $35.9 \%$, and within Punjab (India) there were significant geographical differences from 0 to $86 \%$.

There were no profound clinical signs of iodine deficiency, but the activity of circulating $\mathrm{T} 4$ and the ratio T4: T3 increased in response to injection of iodinated oil and remained for more than 70 days after injection.

According to the authors, the reaction to iodine is the most reliable indicator of thyroid dysfunction associated with iodine deficiency [5].

Iodine deficiency in the body of animalsdisrupts the biosynthesis of thyroid hormones, which leads to a decrease in the intensity of redox processes, as a result of which all types of metabolism are disrupted: protein, fat, carbohydrate, macro- and microelement, energy. In this regard, the malfunction of the thyroid gland is accompanied by the development of severe pathological biochemical processes, which, in the end, leads to the clinical manifestation of the disease. Iodine deficiency in cows is most often manifested by articular pathology with the development of arthritis and arthroses, pregnancy pathology and impaired reproductive function [5].

Taking into account the fact that in conditions of continuous iodine deficiency it is very difficult to ensure animal health, the issues of iodine deficiency prevention are economically important for industrial animal husbandry [7, 8].

It is no coincidence that the countries with natural iodine deficiency have developed public programs for the use of iodine-containing additives in diets [9-15].

Iodization of feed for livestock and birds, in addition to increasing the content of iodine in livestock products, is also a means of combating iodine deficiency in animals. The EU countries have adopted the safest level of iodine in chicken feed to obtain iodized eggs from them $(5000 \mu \mathrm{g} / \mathrm{kg})$. This level of iodine allows only taking care of the health of a bird, but also getting eggs with iodine content of up to $70 \mu \mathrm{g} / \mathrm{egg}$ [16].

The most common and easy way to overcome iodine deficiency for people is to include iodized salt in the diet, however, this method in practical veterinary medicine cannot be considered optimal for a number of circumstances, since it excludes the possibility of individual dosing.

Iodine concentration in the iodized salt is unstable and during storage is significantly reduced, up to complete loss. According to the results of the experiment, a sharp drop in iodine concentration occurs in the first week (losses up to $40 \%$ ). Further, the concentration decreases more smoothly -2 months after the first sampling the microelement content fell by an average of only $15 \%$.

Light exposure is an adverse factor for the preservation of iodine in salt. A week later, iodine losses from the initial concentration averaged $38 \%$ for potassium iodate and $62 \%$ for potassium iodide [4].

Besides, inorganic iodine compounds (potassium iodide or sodium) are converted into non-digestible forms for the body, or have a toxic effect on thyrocytes by accumulating in a large amount in the thyroid gland. A more rational approach to the prevention of iodine deficiency, including to ensurethe optimal regulation of metabolic processes in the body, may be the use of organic forms of iodine or chelate compounds $[12,13]$.

Given this circumstance, we have determined the direction of study on the development of iodomethabolic complex suitable for parenteral use.

\section{Purpose of the study}

To developaiodomethaboliccomplex based on iodine iodide with polyvinyl alcohol (iodinol) and succinic acid and evaluate its effectiveness for correction of energymetabolical disorders at pronounced iodine deficiency in calves.

Iodinol was used as iodine-polymer complex. Iodinolis an aqueous solution consisting of iodine $(0.1 \%)$, potassium iodide $(0.9 \%)$, polyvinyl alcohol [17].

Iodinolhas found wide application in medicine and veterinary science [17-21]. Unlike elemental iodine, this drug is low-toxic, has antiviral, antimicrobial and antifungal activity. Bactericidal action develops due to the destruction of microorganism membrane proteins (viruses, bacteria, protozoa, fungi) [21].

Succinic acid is a versatile component widely used to improve the pharmacological activity of medicinal drugs. Succinic acid is used to potentiate the biological activity of immunomodulators and has shown high clinical effectiveness in metabolic disorders and infectious diseases of calves [22-26].

The compound of succinic acid with iodinol made it possible to obtain an energometabolic effect, which prevails the action of individual components [21, 22].

\section{Materials and methods}

The subjects for the studies were calves with clinically expressed signs of iodine deficiency. According to the principle of analogues, 3 groups of calves were formed (two experimental and 1 control, 10 heads each).

The calves of the first test group were given iodomethabolic composition based on iodine iodide with polyvinyl alcohol (iodinol) and sodium succinate, the animals of the second group -pharmacopeialiodinol.

The preparations were administered intramuscularly in a volume of $2.5 \mathrm{ml}(20,000 \mu \mathrm{g}$ iodine $)$, three times, 7 days apart.

Clinical observations and comparison of biochemical blood readings of calves of experienced and control groups were carried out throughout the experiment.

Biochemical studies were carried out on an automatic analyzer EosBravoforte (HospitexDiagnostics, Italy) using Abris diagnostic kits (Russia).

Serum detection of thyroid hormone thyroxine and triiodothyronine was carried out by enzyme immunoassay on TeacanSunriseautomatic analyzer.

\section{Results and discussion}


During clinical examination, a lag in growth and development, impaired hair growth, its peculiar curvature and glossiness, alopecia on the head and body, dermatitis with preferential localization in the area of the distal limbs were established. The skin was characterized by peeling, dryness, increased folding in the neck.

All selected calves showed signs of myxedema (subspecies edema). In two calves the palpation showed an increase in and tuberosity of the thyroid gland.

Table 1.Dynamics of hematological and biochemical indicators

\begin{tabular}{|c|c|c|c|}
\hline Indicator & $\begin{array}{l}1^{\text {st }} \\
\text { experimenta } \\
1 \text { group }\end{array}$ & $\begin{array}{l}2^{\text {nd }} \\
\text { experimenta } \\
1 \text { group }\end{array}$ & $\begin{array}{l}\text { Control } \\
\text { group }\end{array}$ \\
\hline \multicolumn{4}{|l|}{ Background } \\
\hline $\begin{array}{l}\text { Hemoglobin, } \\
\text { g/l }\end{array}$ & $73.4 \pm 1.3$ & $76.0 \pm 1.8$ & $\begin{array}{l}77.2 \pm 1 . \\
6\end{array}$ \\
\hline $\begin{array}{l}\text { Totalprotein, } \\
\text { g/l }\end{array}$ & $62.3 \pm 2.1$ & $63.4 \pm 2.1$ & $\begin{array}{l}63.3 \pm 2 . \\
4\end{array}$ \\
\hline $\begin{array}{l}\text { Glucose, } \\
\mathrm{mmol} / \mathrm{l}\end{array}$ & $1.6 \pm 0.01$ & $1.6 \pm 0.01$ & $\begin{array}{l}1.5 \pm 0.0 \\
4\end{array}$ \\
\hline $\begin{array}{l}\text { Alkalinereserv } \\
\mathrm{e}, \mathrm{wt} \% \mathrm{CO}_{2 \leq}\end{array}$ & $25.6 \pm 0.56$ & $24.3 \pm 0.46$ & $\begin{array}{l}25.2 \pm \\
0.46 \\
\end{array}$ \\
\hline $\begin{array}{l}\text { Calcium, } \\
\mathrm{mmol} / \mathrm{l}\end{array}$ & $2.46 \pm 0.35$ & $2.49 \pm 0.42$ & $\begin{array}{l}2.59 \pm \\
0.54 \\
\end{array}$ \\
\hline $\begin{array}{l}\text { Phosphorus, } \\
\mathrm{mmol} / \mathrm{l}\end{array}$ & $2.15 \pm 0.32$ & $2.25 \pm 0.36$ & $\begin{array}{l}2.19 \pm \\
0.42 \\
\end{array}$ \\
\hline \multicolumn{4}{|l|}{10 days } \\
\hline $\begin{array}{l}\text { Hemoglobin, } \\
\text { g/l }\end{array}$ & $83.5 \pm 2.4$ & $80.5 \pm 2.2$ & $\begin{array}{l}75.3 \pm 2 . \\
1\end{array}$ \\
\hline $\begin{array}{l}\text { Totalprotein, } \\
\text { g/l }\end{array}$ & $69.3 \pm 2.5$ & $69.3 \pm 2.5$ & $\begin{array}{l}69.3 \pm 2 . \\
5\end{array}$ \\
\hline $\begin{array}{l}\text { Glucose, } \\
\mathrm{mmol} / \mathrm{l}\end{array}$ & $2.1 \pm 0.01$ & $1.8 \pm 0.02$ & $\begin{array}{l}1.6 \pm 0.0 \\
2\end{array}$ \\
\hline $\begin{array}{l}\text { Alkalinereserv } \\
\text { e, wt } \% \mathrm{CO}_{2 \leq}\end{array}$ & $38.1 \pm 1.04$ & $28.1 \pm 1.04$ & $\begin{array}{l}25.7 \pm \\
1.12 \\
\end{array}$ \\
\hline $\begin{array}{l}\text { Calcium, } \\
\mathrm{mmol} / \mathrm{l}\end{array}$ & $2.42 \pm 0.32$ & $2.44 \pm 0.38$ & $\begin{array}{l}2.61 \pm \\
0.50\end{array}$ \\
\hline $\begin{array}{l}\text { Phosphorus, } \\
\mathrm{mmol} / 1\end{array}$ & $2.10 \pm 0.35$ & $2.22 \pm 0.38$ & $\begin{array}{l}2.20 \pm \\
0.45\end{array}$ \\
\hline \multicolumn{4}{|l|}{20 days } \\
\hline $\begin{array}{l}\text { Hemoglobin, } \\
\text { g/l }\end{array}$ & $102.3 \pm 4.3$ & $82.3 \pm 3.2$ & $\begin{array}{l}75.5 \pm 3 . \\
0\end{array}$ \\
\hline $\begin{array}{l}\text { Totalprotein, } \\
\text { g/l }\end{array}$ & $71.3 \pm 2.6$ & $71.3 \pm 2.6$ & $\begin{array}{l}71.3 \pm 2 . \\
6\end{array}$ \\
\hline $\begin{array}{l}\text { Glucose, } \\
\mathrm{mmol} / \mathrm{l}\end{array}$ & $2.3 \pm 0.02$ & $1.9 \pm 0.01$ & $\begin{array}{l}1.6 \pm \\
0.05 \\
\end{array}$ \\
\hline $\begin{array}{l}\text { Alkalinereserv } \\
\text { e, wt } \% \mathrm{CO}_{2 \leq}\end{array}$ & $42.5 \pm 1.64$ & $36.5 \pm 1.64$ & $\begin{array}{l}26.5 \pm \\
1.52 \\
\end{array}$ \\
\hline $\begin{array}{l}\text { Calcium, } \\
\mathrm{mmol} / \mathrm{l}\end{array}$ & $2.86 \pm 0.32$ & $2.54 \pm 0.38$ & $\begin{array}{l}2.58 \pm \\
0.42\end{array}$ \\
\hline $\begin{array}{l}\text { Phosphorus, } \\
\mathrm{mmol} / \mathrm{l}\end{array}$ & $1.98 \pm 0.40$ & $2.12 \pm 0.32$ & $\begin{array}{l}2.24 \pm \\
0.45 \\
\end{array}$ \\
\hline
\end{tabular}

During a biochemical blood study, the signs of metabolic acidosis were revealed (alkaline reserve indicators - 24.3-25.6 wt $\% \mathrm{CO}_{2}$ ), energy deficiency (glucose level reduction to $1.2-1.4 \mathrm{mmol} / \mathrm{l}$ ), anemic syndrome (hemoglobin content - 73.4-76.0 g/l), hypoproteinemia (protein level - 62.3-63.4 g/l), calcium phosphorus disorder. These indicators show a profound violation of all types of metabolism.

The results of hematological and biochemical studies are presented in Table 1.

During the observation period under the influence of the iodomethabolic composition the calves of the first experimental group significantly increased the hemoglobin content, which reduced the risk of developing anemic syndrome.

In the first experimental group the indices of total protein and glucose approached the boundaries of the physiological norm. We associate the resulting effect with the high ability of succinic acid and its salts to activate energy metabolism under conditions of hypoxia (anemic syndrome). An increase in the blood alkaline reserveindicates a correction of metabolic acidosis.

Succinic acid has the ability to activate the involvement in the energy exchange of the most problematic substrates, such as lactate and ketoacids $[23,24,25,30]$. Besides, during the metabolic change of succinic acid or its succinate salts, sodium hydroxide is formed, which leads to thedeoxidation of the organism [29].

The use of the immunometabolic composition provided pronounced positive changes in the state of mineral exchange, calves of the first experimental group almost normalized the calcium/phosphorus ratio.

Thyroid hormone content was significantly reduced. Thus, the content of T3 (triiodothyronine) did not exceed $0.75 \mathrm{nM} / \mathrm{l}$, and the level of thyroxin was $11.2-11.7 \mathrm{nM} / \mathrm{l}$, which is significantly lower than normal and in combination with clinical signs indicates iodine deficiency.

The dynamics of the hormonal status of calves was studied during the experiment.

Table 2.Dynamics ofthyroidhormonecontent

\begin{tabular}{|l|l|l|l|}
\hline Indicator & $\begin{array}{l}1^{\text {st }} \\
\text { experimen } \\
\text { tal group }\end{array}$ & $\begin{array}{l}2^{\text {nd }} \\
\text { experimen } \\
\text { tal group }\end{array}$ & $\begin{array}{l}\text { Contr } \\
\text { ol } \\
\text { group }\end{array}$ \\
\hline Background & $0.75 \pm 0.01$ & $0.73 \pm 0.01$ & $\begin{array}{l}0.7 \\
\pm \\
0.02\end{array}$ \\
\hline $\begin{array}{l}\text { Triiodothyronine(n } \\
\text { M/l) }\end{array}$ & $11.2 \pm 1.2$ & $24 \pm 1.8$ & $\begin{array}{l}38 \pm \\
2.6\end{array}$ \\
\hline Thyroxin (nM/l) & $0.95 \pm 0.02$ & $0.81 \pm 0.03$ & $\begin{array}{l}0.76 \pm \\
0.02\end{array}$ \\
\hline 10 days & $11.6 \pm 1.6$ & $18 \pm 2.5$ & $\begin{array}{l}24 \pm \\
3.2\end{array}$ \\
\hline $\begin{array}{l}\text { Triiodothyronine } \\
\text { (nM/l) }\end{array}$ & & $1.12 \pm 0.07$ & $\begin{array}{l}0.82 \pm \\
0.02\end{array}$ \\
\hline Thyroxin (nM/l) & $1.86 \pm 0.05$ & $\begin{array}{l}11.4 \pm \\
2.1\end{array}$ \\
\hline 20 days & $11.7 \pm 2.4$ & $11.5 \pm 1.8$ \\
\hline $\begin{array}{l}\text { Triiodothyronine } \\
\text { (nM/l) }\end{array}$ & & & \\
\hline \begin{tabular}{l} 
Thyroxin (nM/l) \\
\hline
\end{tabular} &
\end{tabular}

The content of triiodothyroninewas significantly $(p<0.05)$ increased in the calves of the first experimental group approaching the boundary of the physiological norm. The hormone content in the blood of calves of the 
second experimental group did not increase significantly, but in the control group it remained almost the same.

The thyroxin content in the first test group of calves has risen reliably $(p<0.05)$. In the second experimental group the increase was less pronounced, and in the control group there was a slight decrease in thyroxin content compared to background values.

Clinical observations showed that a day after the first administration of the iodomethabolic composition theappetite of calves has improved.

On day 17-20 the calves on which the iodomethabolic composition was tested showed hair growth in areas with alopecia and an improvement in the overall state of the hair cover. The symptoms of myxedema were reduced, the calves became more active. However, within the specified time frame dermatological symptoms did not completely disappear. In our opinion, this may be caused by a shortage of other microelements.

\section{Conclusion}

Based on the obtained data we believe that the injection of a complex drug based on iodine-iodide with polyvinyl alcohol (iodinol) and succinic acid salt ensured the normalization of energy and metabolic disorders in calves with clinically pronounced iodine deficiency.

\section{References}

1. N.M. Platonova Clinical and experimental study. 11(1), 12-20, (2015).

2. N.M. Platonova Iodine deficiency disorders (prevention, diagnosis, treatment and monitoring), $\mathrm{PhD}$ dissertation abtract, Moscow, 2010.

3. S.A. Manukalo, A.Kh. Shantyz Veterinary Science of Kuban, 5, (2014).

4. N.N. Khodyrevskaya, Ecological monitoring of iodine in biogeocenoses of hayfields of the Central Chernozem Region, $\mathrm{PhD}$ dissertation, Bryansk State Agricultural Academy, (2009).

5. C. S. Randhawa, S. S. Randhawa Australian veterinary journal.79 (5), 349-351,(2001)

6. R. W. Hemken Journal of dairy science,53(8), 1138-1143, (1970).

7. A.Kh. Shantyz, Prospects of iodine-containing drugs in veterinary medicine. $\mathrm{PhD}$ dissertation abtract, Krasnodar, (2015).

8. A.A. Evglevsky, V.N. Skira, G.F. Ryzhkova, I.I. Mikhailova, Bulletin of Russian Agricultural Sciences, 2, 67-70 (2019).

9. Li Mu, Creswell J. Eastman, Kay V. Waite, Gary Ma, Margaret R. Zacharin, Duncan J. Topliss, Philip E. Harding, John P. Walsh, Lynley C. Ward, Robin H. Mortimer, Emily J. Mackenzie, Karen Byth and Zelda Doyle. Results of the Australian National IodineNutrition Study MJA, 184 (4) (2006).
10. G. Jahreis, W. Hausmann, G. Kiesling, K. France, M. Leather Experimental and Clinical Endocrinology and Diabetes, 109(03), 163-167 (2001).

11. N. Bader, U. Möller, M. Leiterer, K. Franke, G. Jahreis Thuringia.(2003)

12. L. Rasmussen, L. Ovesen, I. Bulow, T. Jorgensen, N. Knudsen, P. Laurberg, H. Perrild, British Journal of Nutrition 87, 61-69(2002).

13. E. Pearce, S. Pino, X. He, H.R. Bazrafshan, S.L. Lee, L.E. Braverman Journal of clinical Endocrinology and metabolism,89(7), 3412-3424, (2004)

14. G. Jahreis, M. Leather, K. France, W. Maichrowitz, F. Schone, Kinderpraxis 16, 172181 (1999).

15. M.A. McCoy et al. Veterinary Record. 141(21), 544-547, (1997).

16. FEEDAP PANEL, EFSA European Food SaferyAuthority Journal. 168, (2005):

17. V.O. Mokhnach, A.V. Waldman, P.D. Evdokimov Iodinol in medicine and veterinary science. (L.: Science.1967).

18. Patent of the Russian Federation No. 2664438 Method of preventing iodine deficiency and correcting metabolism in cows.(17.08.2018).

19. A.A. Evglevsky, I.I. Mikhaylova, E.P. Evglevskaya, N.V. Vanina, T.A. Evglevskay Bulletin of Kursk State Agricultural Academy 8, (2015).

20. I.V. Mokhnach, Repressed science.2, 145-157 (1994).

21. O.A. Abdullaev, A.V. Sergienko, M.N. Ivashev International Journal of Experimental Education, 3-2, 47-48, (2015)

22. A.L. Kovalenko, N.V. Belyakova Pharmacy,5-6, 40-42, (2000).

23. A.F. Lebedev, O.M. Shvets, A.A. Evglevsky, E.P. Evglevskaya, et al. Veterinary Science.3, 48-51, (2009).

24. Yu.Yu. Ivnitsky, A.I. Golovko, G.A. Safronov Succinic acid in the system of metabolic correction of functional state of body resistance. (1998).

25. E.I. Maevsky, B.V. Grishina, A.S. Rosenfeld Effectiveness of dietary supplement application in various fields of medicine: Collection of materials of scientific and practical conference on biologically active additives. pp. 261-265. (2000).

26. M.N. Kondrashova Therapeutic effect of succinic acid (Puschino, 1976).

27. A.A. Evglevsky, E.P. Evglevskaya, I.I. Mikhaylova, N.V. Vanin Bulletin of Russian Agricultural Sciences, 4, 61-64, (2017).

28. A.S. Rosenfeld, Maintaining physical performance by metabolic correction of acidosis. PhD dissertation abtract (Pushchino, 2001). 